\title{
Anti-tumor effect of inhibition of IL-6 signaling in mucoepidermoid carcinoma
}

\author{
Daiki Mochizuki, ${ }^{1,2}$, April Adams ${ }^{1}$, Kristy A. Warner ${ }^{1}$, Zhaocheng Zhang ${ }^{1}$, Alexander \\ T. Pearson ${ }^{1,3}$, Kiyoshi Misawa ${ }^{2}$, Scott A. McLean ${ }^{4}$, Gregory T. Wolf ${ }^{4}$ and Jacques E. \\ Nör $1,4,5,6$ \\ ${ }^{1}$ Department of Restorative Sciences, University of Michigan School of Dentistry, Ann Arbor, Michigan, USA \\ 2 Department of Otolaryngology/Head Neck Surgery, Hamamatsu University School of Medicine, Hamamatsu, Shizuoka, \\ Japan \\ ${ }^{3}$ Division of Hematology/Oncology, Department of Internal Medicine, University of Michigan School of Medicine, Ann Arbor, \\ Michigan, USA \\ ${ }^{4}$ Department of Otolaryngology, University of Michigan School of Medicine, Ann Arbor, Michigan, USA \\ ${ }^{5}$ Department of Biomedical Engineering, University of Michigan College of Engineering, Ann Arbor, Michigan, USA \\ ${ }^{6}$ Comprehensive Cancer Center, University of Michigan, Ann Arbor, Michigan, USA \\ Correspondence to: Jacques E. Nör DDS, email: jenor@med.umich.edu
}

Keywords: salivary gland cancer, tumorigenesis, tocilizumab, IL-6R, tumor initiating cells

Received: April 06, $2015 \quad$ Accepted: May 30, $2015 \quad$ Published: June 15, 2015

This is an open-access article distributed under the terms of the Creative Commons Attribution License, which permits unrestricted use, distribution, and reproduction in any medium, provided the original author and source are credited.

\section{ABSTRACT}

Mucoepidermoid carcinoma (MEC) is the most frequent malignant salivary gland cancer. Response to chemoradiotherapy is modest, and therefore radical surgery remains the standard-of-care. Emerging evidence suggests that Interleukin (IL)-6 signaling correlates with the survival of cancer stem cells and resistance to therapy. Here, we investigated whether inhibition of IL-6 receptor (IL-6R) signaling with tocilizumab (humanized anti-human IL-6R antibody) sensitizes MEC to chemotherapy using human mucoepidermoid carcinoma cell lines (UM-HMC) and correspondent xenograft models. In vitro, we observed that tocilizumab inhibited STAT3 phosphorylation but had no measurable effect in MEC cell viability (UM-HMC$1,-3 A,-3 B)$. In contrast, the anti-tumor effect of single agent tocilizumab on MEC xenografts was comparable to paclitaxel or cisplatin. Combination of tocilizumab with cisplatin or paclitaxel enhanced the inhibitory effect of chemotherapy on xenograft growth $(P<0.05)$, time to failure $(P<0.01)$, decreased vascular endothelial growth factor (VEGF) expression and tumor microvessel density $(P<0.05)$ without added systemic toxicities. Notably, tocilizumab decreased the fraction of MEC cancer stem cells (ALDH ${ }^{\text {high }}$ CD44 ${ }^{\text {high }}$ ) in vitro, and prevented paclitaxel-induced increase in the fraction of cancer stem cells in vivo $(P<0.05)$. Collectively, these findings demonstrate that tocilizumab enhances the anti-tumor effect of conventional chemotherapy in preclinical models of mucoepidermoid carcinoma, and suggest that patients might benefit from combination therapy with an inhibitor of IL-6R signaling and chemotherapeutic agent such as paclitaxel.

\section{INTRODUCTION}

Salivary gland cancers are complex and diverse malignancies comprised of 24 morphologically different neoplasms [1-4]. Mucoepidermoid carcinoma (MEC) is the most common malignant salivary gland cancer, histologically characterized as a glandular epithelial neoplasm containing mucous, intermediate, and epidermoid cells [4-6]. Histological grading correlates well with clinical behavior. As such, the 5 -year survival for low or intermediate grade tumors is $85-98 \%$, while for high grade tumors is only $22-55 \%$ 
[6-11]. Mucoepidermoid carcinomas are characterized by relentless growth and resistance to systemic therapy and radiotherapy. Therefore, the most effective therapy remains radical surgery, which is typically accompanied by severe facial disfigurement, loss of function, and major consequences to the quality of life of patients $[5,12-$ 16]. The development of a mechanism-based therapeutic strategy that sensitizes these tumors to chemotherapy can potentially enhance the survival and quality of life of patients with mucoepidermoid carcinoma.

Interleukin-6 (IL-6) enhances the survival of cancer stem cells (CSC) in several tumors including glioma and breast cancer [17, 18], and increases the conversion of non-cancer stem cells into cancer stem cells in breast cancer models [19]. Downstream mediators of IL-6 signaling (e.g. JAK/STAT3, PI3K, NF-кB) strongly correlate with the pathobiology of several malignancies [20-25]. In head and neck cancer, serum IL-6 levels correlate with poor prognosis $[26,27]$. We have recently showed that cancer stem cells reside in the perivascular niche of head and neck squamous cell carcinomas [28], and that endothelial cell-secreted IL-6 enhances the survival, self-renewal, and tumorigenic potential of cancer stem cells [29]. We also observed that cisplatin treatment enhances the fraction of cancer stem cells in head and neck tumors [30]. We have recently observed that salivary mucoepidermoid carcinomas contain a sub-population of uniquely tumorigenic cancer stem cells, defined as $\mathrm{ALDH}^{\text {high }} \mathrm{CD} 44^{\text {high }}$ cells. It is believed that cancer stem cells play a critical role in resistance to therapy in many glandular malignancies. However, it is unclear if IL-6 signaling is involved in the survival of cancer stem cells and the resistance to chemotherapy observed in patients with mucoepidermoid carcinoma.

Progress in the development of effective therapies for mucoepidermoid carcinoma has been hindered by the lack of experimental models. However, the recent characterization of mucoepidermoid carcinoma cell lines and accompanying xenograft models generated from patients with resistant disease [28] has finally enabled mechanistic studies and the testing of new therapies. Here, we evaluated the anti-tumor effect of tocilizumab, a humanized anti-human IL-6R antibody, in combination with conventional chemotherapy (cisplatin or paclitaxel) in preclinical models of mucoepidermoid carcinoma. We observed that therapeutic inhibition of IL-6R with tocilizumab enhanced the in vivo anti-tumor effect of both conventional chemotherapeutic agents tested here, despite having no direct effect on the survival of unsorted mucoepidermoid carcinoma cells in vitro. Notably, tocilizumab treatment caused a decrease in the microvessel density of xenograft tumors, and prevented paclitaxel-induced increase in the fraction of cancer stem cells. Collectively, these data demonstrate that therapeutic inhibition of IL-6R signaling with tocilizumab potentiates the anti-tumor effect of conventional chemotherapeutic drugs in preclinical models of mucoepidermoid carcinoma, and suggests that patients might benefit from the combined administration of tocilizumab and paclitaxel.

\section{RESULTS}

\section{Expression of key mediators of IL-6 signaling in mucoepidermoid carcinoma}

To begin to understand the therapeutic potential of targeting IL-6 signaling in mucoepidermoid carcinomas, we evaluated the expression of key components of the IL-6 pathway in primary human tumors and in our xenograft models (Supplementary Figure S1). We observed that the xenograft tumors generated with UM-HMC cell lines reproduced the typical morphology of primary human tumors, with areas of predominantly cystic, while other areas with more of a solid appearance (Supplementary Figure S1A). Immunofluorescence staining revealed that the IL-6 ligand, both receptors (i.e. IL-6R, gp130) and the key downstream effector pSTAT3 are highly expressed in these tumors (Supplementary Figure S1B and S1C). Notably, both human and xenograft tumors showed largely similar patterns of expression of these molecules (Supplementary Figure S1C). These descriptive results suggested that IL-6 could potentially play a significant role in the pathobiology of mucoepidermoid carcinoma, and encouraged us to perform developmental therapeutic studies with tocilizumab, a humanized anti-IL-6R antibody that has been approved by the FDA for treatment of rheumatoid arthritis since 2010.

\section{Tocilizumab inhibits the growth of mucoepidermoid carcinomas}

In pilot experiments, we observed that single agent tocilizumab inhibited tumor growth to the same extent as single agent paclitaxel or cisplatin (Supplementary Figure S2A and S2C). While tocilizumab was well tolerated without causing a noticeable decrease in mouse weight, we observed a $10 \%$ weight loss in mice that received $20 \mathrm{mg} / \mathrm{kg}$ paclitaxel (Supplementary Figure S2A). Notably, the combination of tocilizumab with paclitaxel or cisplatin potentiated the overall effect of therapy leading to a tumoristatic effect without added toxicities (Supplementary Figure S2). The results of this pilot experiment suggested that IL-6R inhibition with tocilizumab have a therapeutic effect in preclinical models of mucoepidermoid carcinoma, and informed our decision to decrease the dose of paclitaxel to $15 \mathrm{mg} / \mathrm{kg}$ for the remaining studies.

When we repeated these experiments using a larger sample size $(n=8-10)$, the overall trends were similar to those observed in the pilot experiment (Figure 1). We 
A

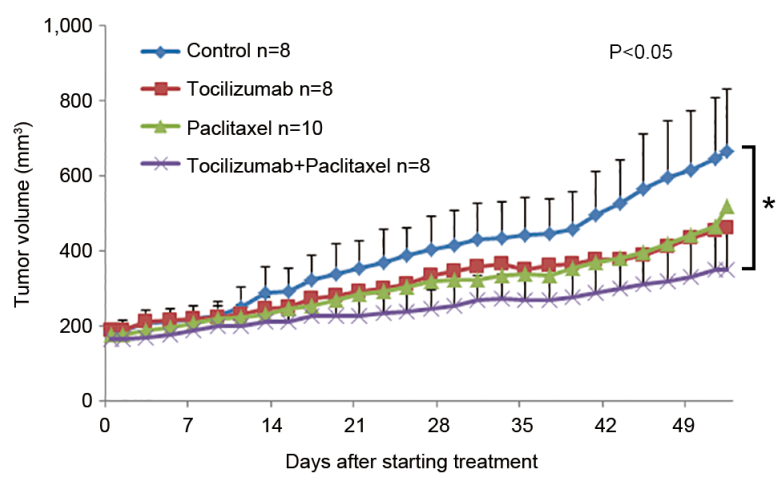

C

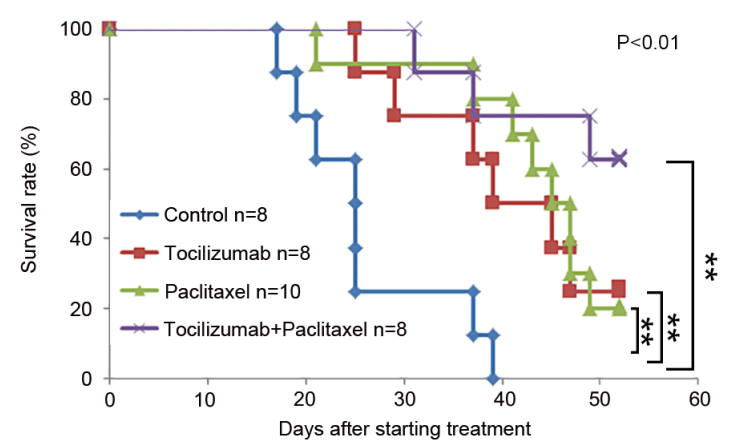

E

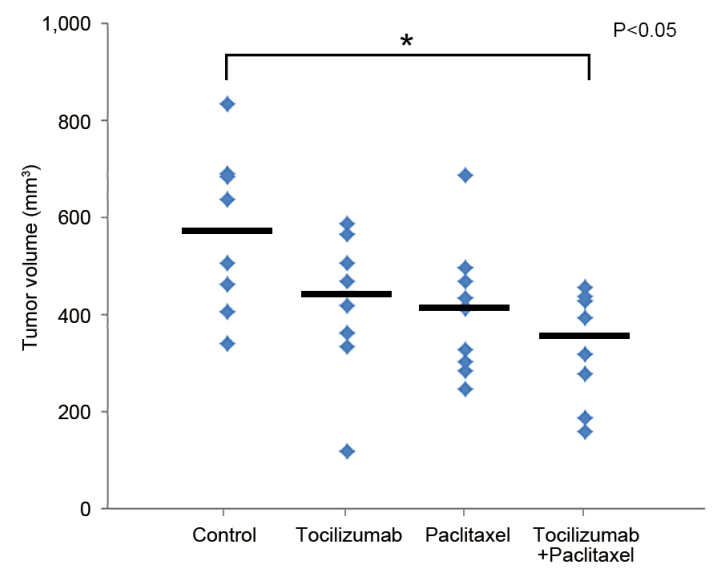

B

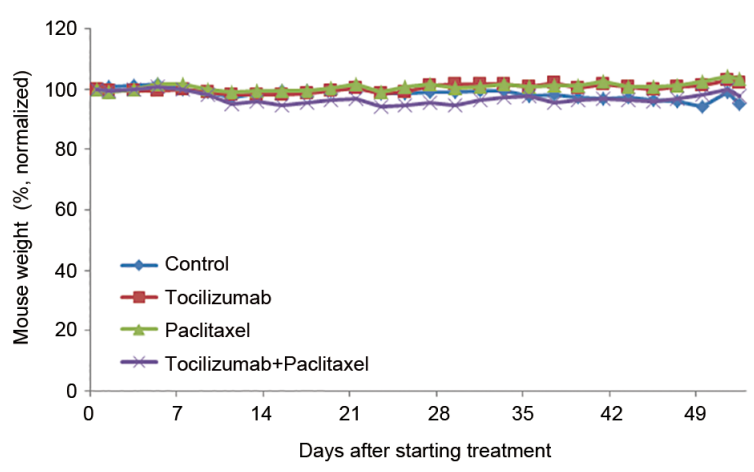

D
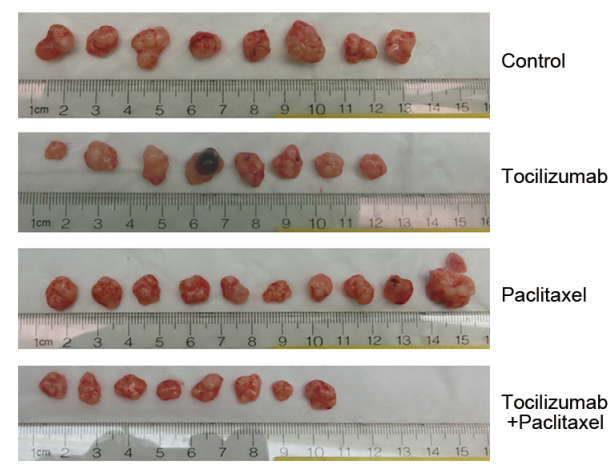

$\mathbf{F}$

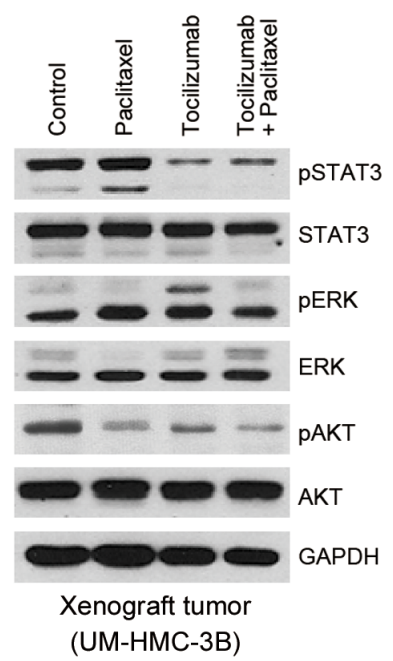

Figure 1: Effect of tocilizumab and/or paclitaxel in preclinical models of mucoepidermoid carcinoma. Xenograft tumors were generated in immunodeficient mice upon transplantation of UM-HMC-3B cells. When tumors reached $200 \mathrm{~mm}^{3}$, mice were randomized into the 4 different treatment regimens as follows: $5 \mathrm{mg} / \mathrm{kg}$ IgG control, $5 \mathrm{mg} / \mathrm{kg}$ tocilizumab, $15 \mathrm{mg} / \mathrm{kg}$ paclitaxel, or $15 \mathrm{mg} / \mathrm{kg}$ paclitaxel combined with $5 \mathrm{mg} / \mathrm{kg}$ tocilizumab weekly via i.p. injection. A. Graph depicting tumor volume over time until the first tumors in the control group reached the cutoff size of $1,000 \mathrm{~mm}^{3}$. Tocilizumab with paclitaxel group has a significant effect on tumor volume compared with control group $(P<0.05)$. B. Graph depicting mouse weight during treatment. Data were normalized against pre-treatment weight. C. Kaplan-Meier analysis using as criterion for failure a 2-fold increase in tumor volume as compared with pre-treatment tumor volume. Paclitaxel with tocilizumab group extended time to failure significantly compared with control group, and single drug groups, tocilizumab and paclitaxel, also extended compared with control group $(P<0.01)$. D. Macroscopic view of xenografts tumors upon retrieval from the mice. E. Graph depicting the volume of each individual xenograft tumor. Asterisk $\left(^{*}\right)$ depicts a statistical difference between control and tocilizumab + paclitaxel group $(P<0.05)$. F. Western blot for phosphorylated and total STAT3, AKT, and ERK in the tumors treated with tocilizumab and/or paclitaxel as compared to vehicle control. Tumors were harvested 10 days after last dose of drugs. 
observed that tocilizumab with paclitaxel or cisplatin group had a significant effect on tumor volume compared with control group (Figure $1 \mathrm{~A}$ and $2 \mathrm{~A}, P<0.05$ ), and single agent tocilizumab showed significant tumor growth inhibition, similar to single agent paclitaxel (Figure 1A and $1 \mathrm{C}-1 \mathrm{E}$ ) or cisplatin (Figure 2A, 2C and 2D), without noticeable systemic toxicities (Figure $1 \mathrm{~B}$ and $2 \mathrm{~B}$ ). Western blots of the tumor tissues retrieved from the mice at the end of the experiments revealed that tocilizumab, but not paclitaxel, inhibited the main downstream effector of IL-6 signaling, i.e. phosphorylated STAT3 (Figure 1F). Interestingly, tocilizumab and/or paclitaxel inhibited the AKT signaling pathway, a key regulator of tumor cell survival (Figure 1F). Kaplan-Meier analyses using as criterion for "event" a 2-fold increase in tumor volume as compared to pre-treatment size, showed significant tumor inhibition for single agent Tocilizumab $(P<0.01)$, when compared to vehicle control (Figure 1C). Notably, we observed even more marked tumor inhibition when tocilizumab was used in combination with paclitaxel

A

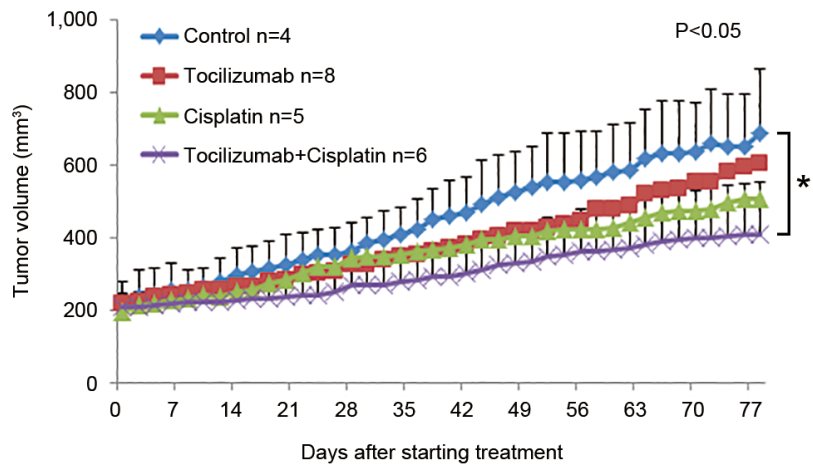

C

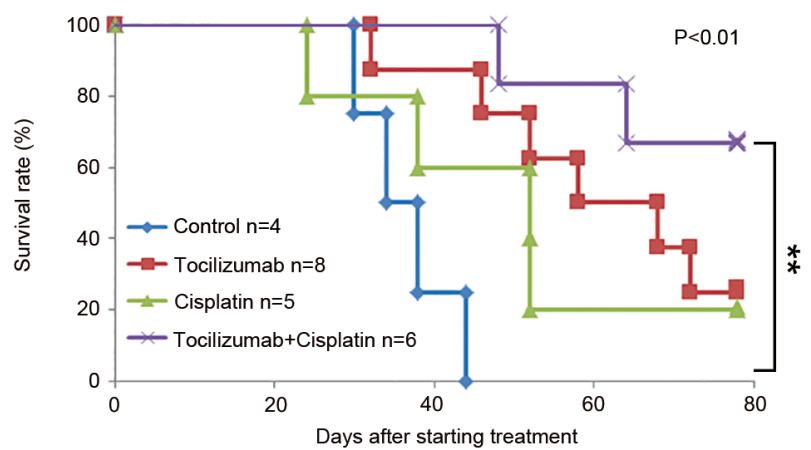

(Figure 1C) or cisplatin (Figure 2C), when compared to controls $(P<0.01)$. Calculation of tumor growth inhibition (TGI) index confirmed previous results, demonstrating an overall anti-tumor effect for Tocilizumab that was comparable with single agent conventional chemotherapy, and a significant potentiation of this effect when the targeted drug was combined with Paclitaxel (Supplementary Figure S3).

\section{Tocilizumab is not cytotoxic to mucoepidermoid carcinoma cells in vitro}

To understand potential mechanisms underlying the in vivo anti-tumor effect of tocilizumab, we performed a series of in vitro experiments. Cell viability assays using a panel of mucoepidermoid carcinoma cell lines (UMHMC-1,-3A,-3B) and primary human endothelial cells (HDMEC) revealed that the overall $\mathrm{IC}_{50}$ for cisplatin ranged between $0.99-1.75 \mu \mathrm{mol} / \mathrm{L}$, while the $\mathrm{IC}_{50}$ for
B

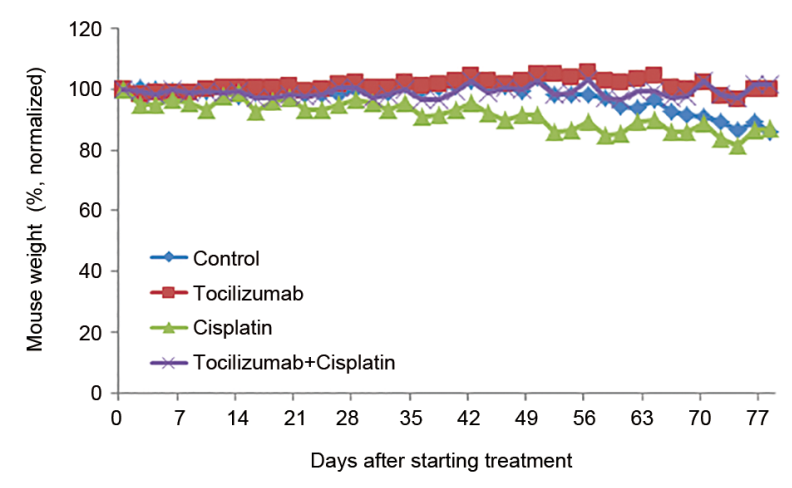

D

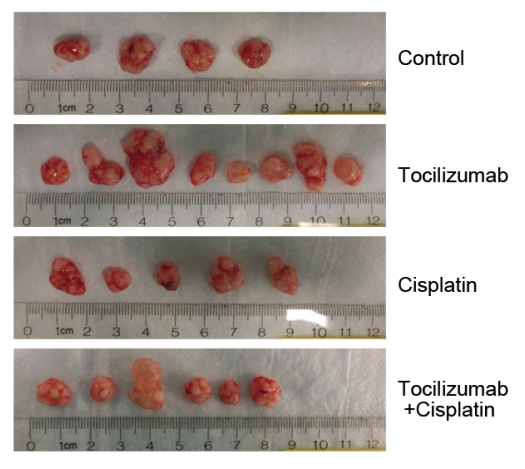

Figure 2: Effect of tocilizumab and/or cisplatin in preclinical models of mucoepidermoid carcinoma. Xenograft tumors were generated in immunodeficient mice upon transplantation of UM-HMC-3B cells. When tumors reached $200 \mathrm{~mm}^{3}$, mice were randomized into the 4 different treatment regimens as follows: $5 \mathrm{mg} / \mathrm{kg} \mathrm{IgG}$ control, $5 \mathrm{mg} / \mathrm{kg}$ tocilizumab, $15 \mathrm{mg} / \mathrm{kg}$ cisplatin, or $15 \mathrm{mg} / \mathrm{kg}$ cisplatin combined with $5 \mathrm{mg} / \mathrm{kg}$ tocilizumab weekly via i.p. injection. A. Graph depicting tumor volume over time until the first tumors in the control group reached the cutoff size of $1,000 \mathrm{~mm}^{3}$. Tocilizumab with cisplatin group has a significant effect on tumor volume compared with control group $(P<0.05)$. B. Graph depicting mouse weight during treatment. Data were normalized against pre-treatment weight. C. Kaplan-Meier analysis using as criterion for failure a 2-fold increase in tumor volume as compared with pre-treatment tumor volume. Cisplatin with tocilizumab group extended time to failure significantly compared with control group $(P<0.01)$. D. Macroscopic view of xenografts tumors upon retrieval from the mice. 
paclitaxel was $24 \mathrm{nmol} / \mathrm{L}$ in endothelial cells and 0.75 to $2.89 \mathrm{nmol} / \mathrm{L}$ in UM-HMC cell lines (Figure 3A-3D). In contrast, Tocilizumab had no measurable cytotoxic effect in the panel of cells evaluated here (Figure 3A-3D). We also investigated the effect of combination therapy with cisplatin or paclitaxel and observed that tocilizumab does not have a significant impact in cell density (Figure 3E) or cell cycle (Figure 3F). We repeated these experiments with the other 2 UM-HMC cell lines and with endothelial cells, and observed similar results (data not shown). Collectively, these experiments indicated that tocilizumab does not have a direct effect on the survival of human mucoepidermoid carcinoma cells.

\section{Tocilizumab decreases tumor microvessel density}

As we were analyzing histologically the xenograft tumors, we observed that perhaps therapeutic inhibition of IL-6R signaling with tocilizumab had an anti-angiogenic effect in vivo despite the lack of a direct cytotoxic effect to endothelial cells in vitro. Indeed, we observed a decrease $(P<0.01)$ in tumor microvessel density when tocilizumab was used alone or in combination with paclitaxel (Figure 4A and 4B). Furthermore, VEGF expression was decreased when single agent tocilizumab or combination of tocilizumab with paclitaxel group was used in vivo (Figure 4C), providing a putative mechanism for the antiangiogenic effect of tocilizumab described above. We have shown that endothelial cells secrete IL-6, CXCL8, and EGF that induce phosphorylation of STAT3, AKT, and ERK in tumor cells, and that these phosphorylation events enhance tumor cell survival and migration [3133]. We have recently demonstrated that endothelial cell-secreted IL-6 regulates the rate of tumor growth via STAT3 signaling [34]. Considering the inhibitory effect of tocilizumab on constitutively active STAT3 in UMHMC-1 cells (Figure 4D) and on IL-6-induced pSTAT3 in UM-HMC-3B (Figure 4E), we performed a series of experiments using endothelial cell conditioned medium as a source of IL-6 in an attempt to mimic endothelial cell-cancer cell interactions observed in the perivascular area [31-34]. We observed a potent induction of STAT3 phosphorylation upon exposure of mucoepidermoid carcinoma cells (UM-HMC-3A,-3B) to endothelialconditioned medium, which was partially blocked in a dose-dependent manner with increasing concentrations of tocilizumab (Figure 4F and 4G). We concluded from these experiments that tocilizumab interferes with the crosstalk between endothelial cells and mucoepidermoid carcinoma cells, with a net anti-angiogenic effect that can explain, at least in part, the overall anti-tumor effect of this drug.
A $\quad$ B

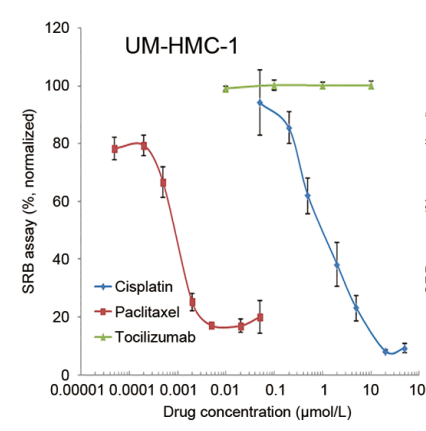

E

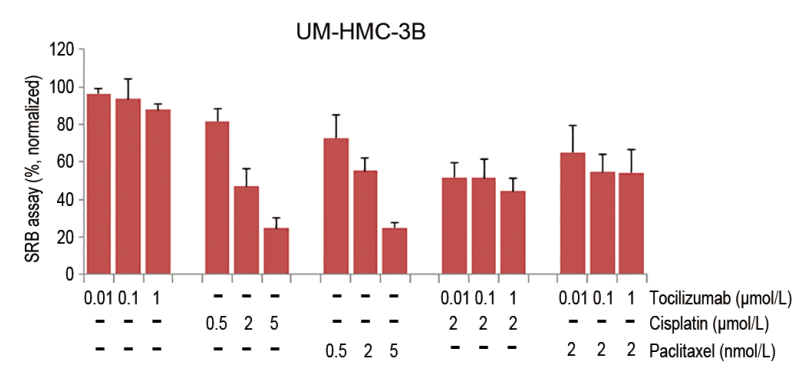

C
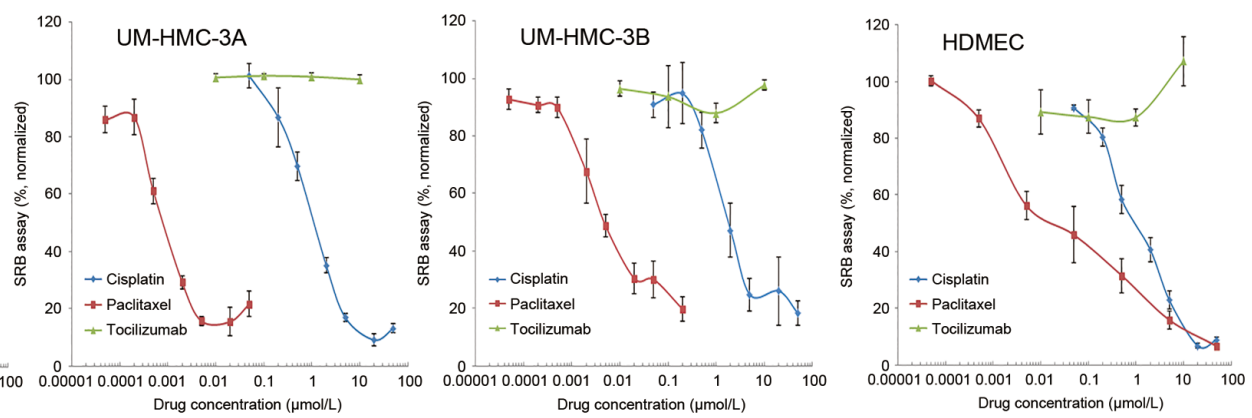

$\mathbf{F}$

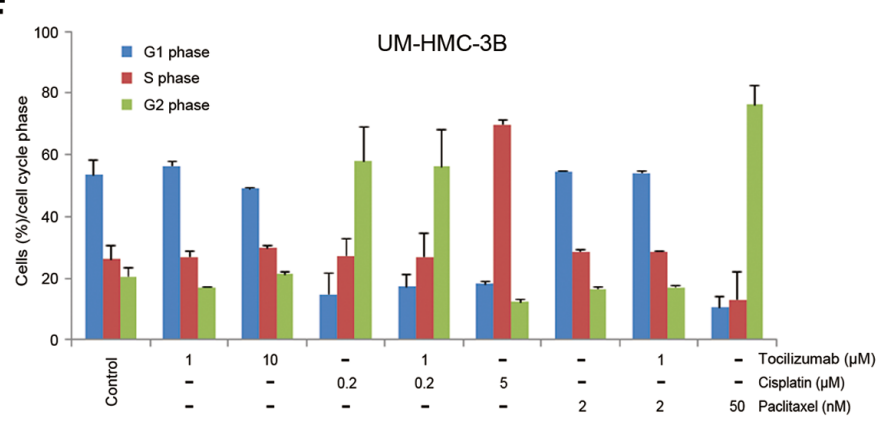

Figure 3: Tocilizumab is not cytotoxic to mucoepidermoid carcinoma cells in vitro. A.-D. Graphs depicting the cytotoxicity of cisplatin, paclitaxel, and tocilizumab in UM-HMC-1, UM-HMC-3A, and UM-HMC-3B, and HDMEC, as determined by SRB assays. Cells were exposed to cisplatin, paclitaxel or tocilizumab for 72 hours. Data were normalized against vehicle control and initial plating density. E. Graph depicting the effect of tocilizumab combination with cisplatin or paclitaxel in UM-HMC-3B cells. Each panel is representative of at least three independent experiments, done in quadruplicate wells per condition. F. Graph depicting the effect of the drugs on cell cycle. Cells were exposed to cisplatin, paclitaxel and/or tocilizumab for 24 hours. Cells were stained with propidium iodide and subjected to flow cytometry for cell cycle analysis. 


\section{Effect of Tocilizumab on cancer stem cells}

We have recently demonstrated the function of a small sub-population of cells endowed with self-renewal and uniquely tumorigenic capacity, namely cancer stem cells, in mucoepidermoid carcinomas. Testing of several putative marker combinations demonstrated that cancer stem cells are identified in mucoepidermoid carcinomas by high aldehyde dehydrogenase (ALDH) activity and CD44
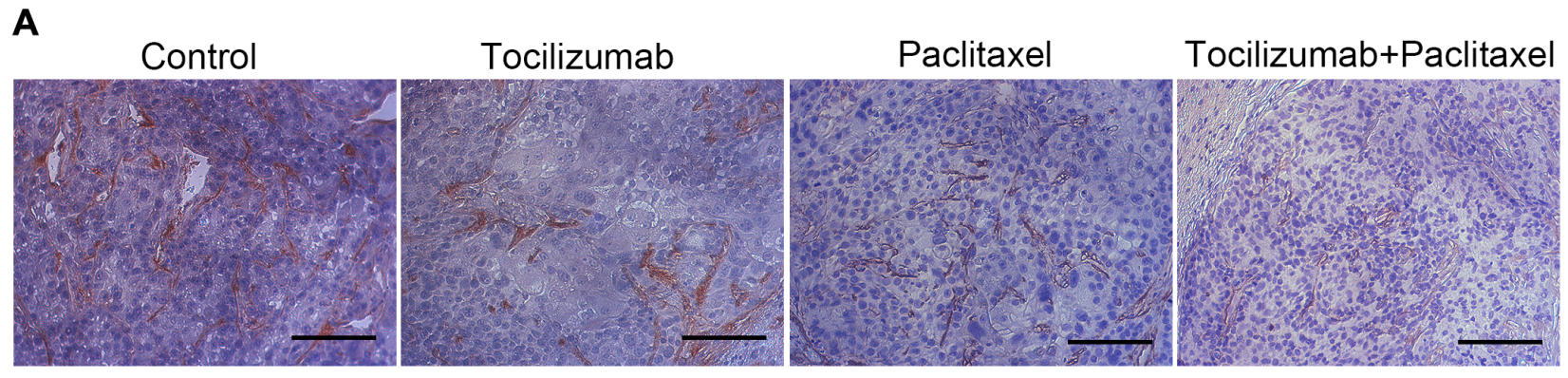

B

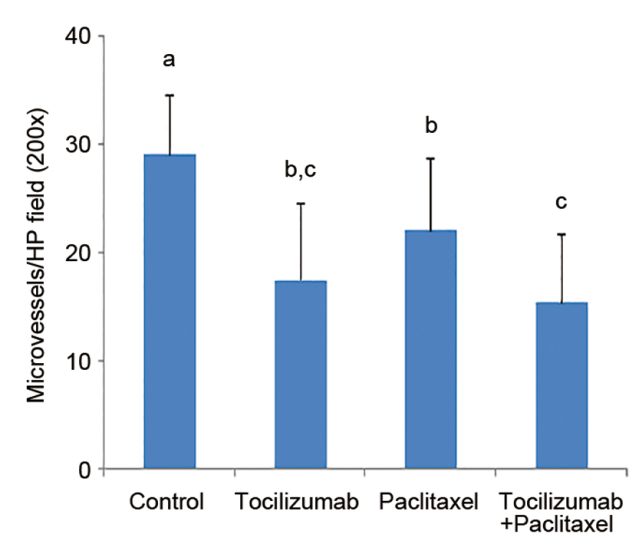

C

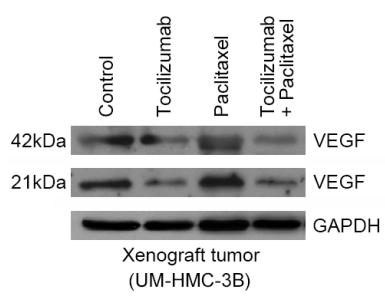

D

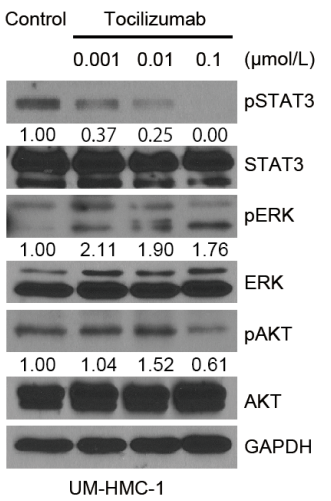

E

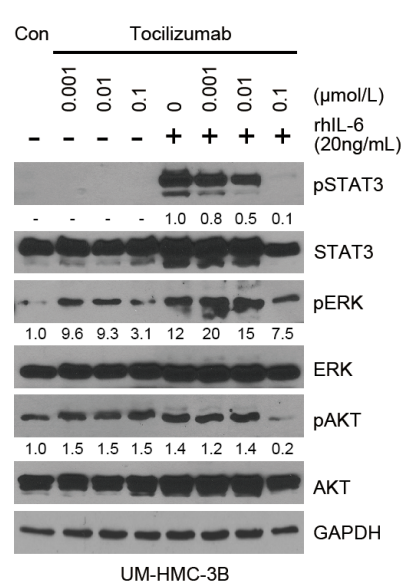

$\mathbf{F}$

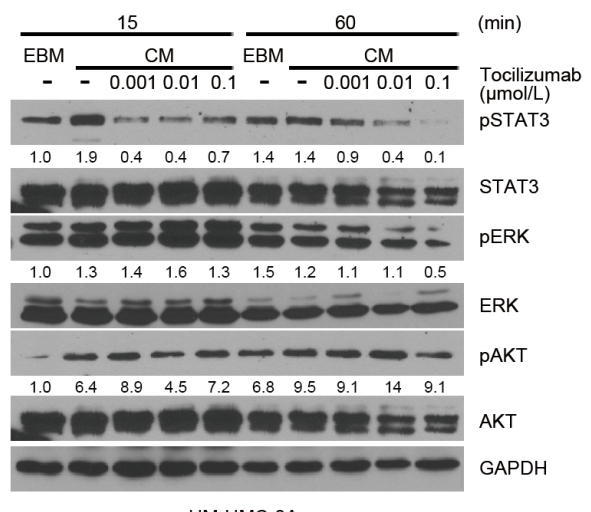

UM-HMC-3A
G

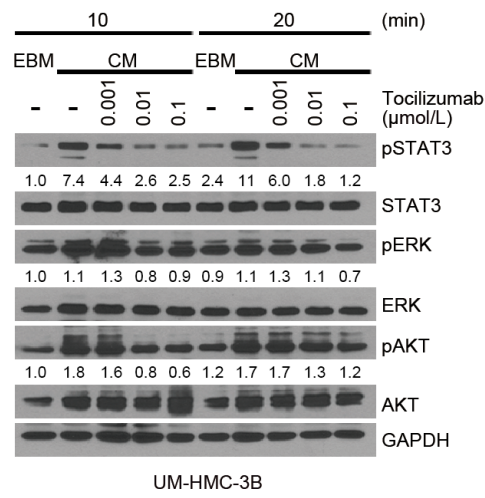

Figure 4: Tocilizumab inhibits tumor microvessel density and STAT3 activity. A. Representative photomicrographs of histologic sections stained for Factor VIII (red) and counterstained with Hematoxylin to identify blood vessels in xenograft tumors. Scale bar represents $100 \mu \mathrm{m}$ at x200 magnification. B. Graph depicting microvessel density in 5 random fields per tumor from 5 tumors per group. Different low-case letters indicate significant differences at $P<0.01$. C. Western blot for VEGF in xenograft tumors. D.-G. Western blots for phosphorylated and total STAT3, AKT, and ERK in UM-HMC cells. UM-HMC-1 cells were incubated with tocilizumab at a range of concentrations from 0.1 to $0.001 \mu \mathrm{mol} / \mathrm{L}$ for 24 hours D. UM-HMC-3B cells were preincubated with tocilizumab at a same range of concentration of 0.1 to $0.001 \mu \mathrm{mol} / \mathrm{L}$ for 1 hour, and then incubated with or without $20 \mathrm{ng} / \mathrm{mL}$ rhIL-6 for 30 min E. Cells (UM-HMC-3A, UM-HMC-3B) were preincubated with tocilizumab at a range of concentrations of 0.1 to $0.001 \mu \mathrm{mol} / \mathrm{L}$ for 2 hours, and then changed medium to endothelial cell conditioned medium (CM) or control unconditioned medium (EBM) in presence of increasing concentrations of tocilizumab F. and G. Quantification of band density was performed with the NIH ImageJ software, using total STAT3, ERK and AKT as reference for band density, and using untreated controls to normalize the data. 
expression ( $\left.\mathrm{ALDH} \mathrm{H}^{\text {high }} \mathrm{CD} 44^{\text {high }}\right)$. To understand the effect of tocilizumab in mucoepidermoid carcinoma stem cells in vitro, we performed sphere assays as we described [35]. While paclitaxel and cisplatin mediated dose-dependent decreases in the number of salispheres generated with unsorted UM-HMC-3B cells (Figure 5A), tocilizumab did not show a measurable effect (Figure 5B). Drug combinations with tocilizumab and paclitaxel or cisplatin followed similar trends of single drug experiments without any noticeable effect for tocilizumab in both, unsorted cells (Figure 5C) or UM-HMC-3B cells FACS-sorted for ALDH and CD44 (Figure 5D). As expected, the number of spheres formed by untreated $\mathrm{ALDH}{ }^{\text {high }} \mathrm{CD} 44^{\text {high }}$ cells was higher than by $\mathrm{ALDH}^{\text {low }} \mathrm{CD} 44^{\text {low }}$ cells (Figure 5D). Collectively, these studies revealed an inhibitory effect for paclitaxel and for cisplatin, and lack of measurable effect for tocilizumab, in cancer stem cells using the in vitro sphere assay in ultra-low attachment plates (Figure 5E).

To investigate the effect of tocilizumab on putative cancer stem cells in vivo, we performed immunofluorescence staining for ALDH1 and CD44 in mucoepidermoid carcinoma xenografts (Figure 6A). As expected, ALDH1 staining was localized in the cytoplasm and was limited to a small sub-set of cells, while CD44 was localized in the cell membrane and presented a more generalized staining pattern (Figure 6A). Interestingly, the fraction of ALDH-positive cells was significantly higher $(P<0.05)$ in the tumor invasive fronts, as compared to the central areas (Figure 6A and 6B). To quantify the effect of therapy on the fraction of cancer stem cells in
A

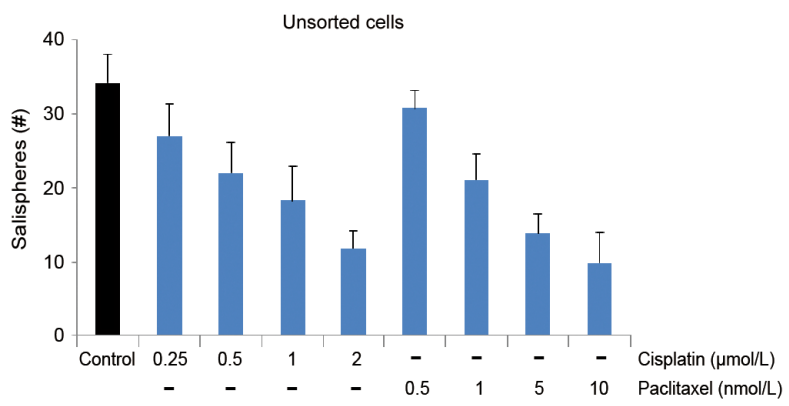

B

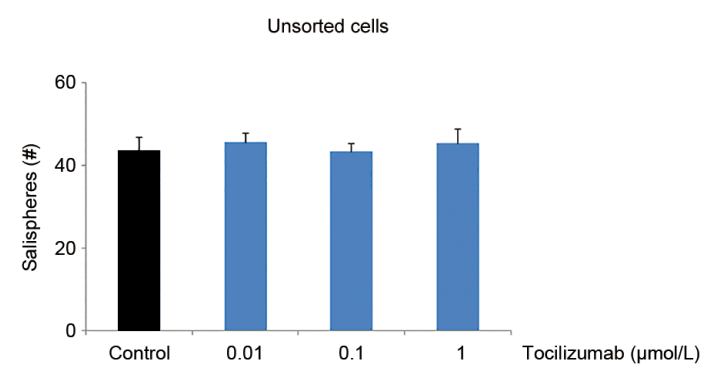

C

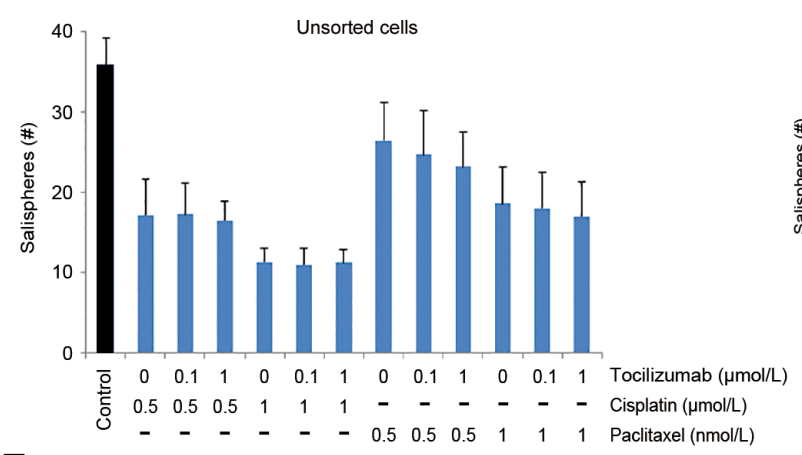

E

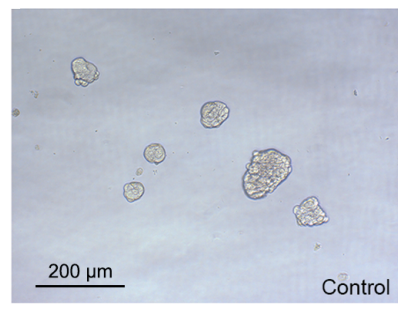

D

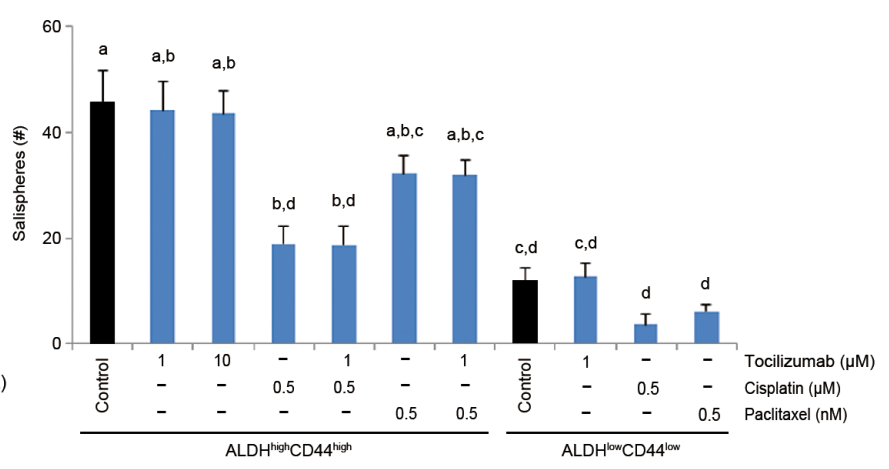

Figure 5: Effect of tocilizumab on cancer stem cells in vitro. Salisphere assays were performed with UM-HMC-3B cells seeded in 96 well plates. A. and B. Graph depicting the number of salispheres when non-sorted (bulk) cells were exposed to cisplatin, paclitaxel A. or tocilizumab B. for 5 days. C. Graph depicting the number of salispheres formed by non-sorted (bulk) cells exposed to cisplatin or paclitaxel in combination with tocilizumab for 5 days. D. Graph depicting the number of salispheres formed by FACS-sorted ALDH high $^{\text {hig }} 44^{\text {high }}$ or $\mathrm{ALDH}^{\text {low }} \mathrm{CD} 44^{\text {low }}$ cells exposed to cisplatin or paclitaxel in combination with tocilizumab for 5 days. Different low-case letters indicate significant difference among groups $(P<0.05)$. E. Photomicrographs of representative salispheres using bulk cells. Scale bars represent $200 \mu \mathrm{m}$ at $\times 100$ magnification. 
A
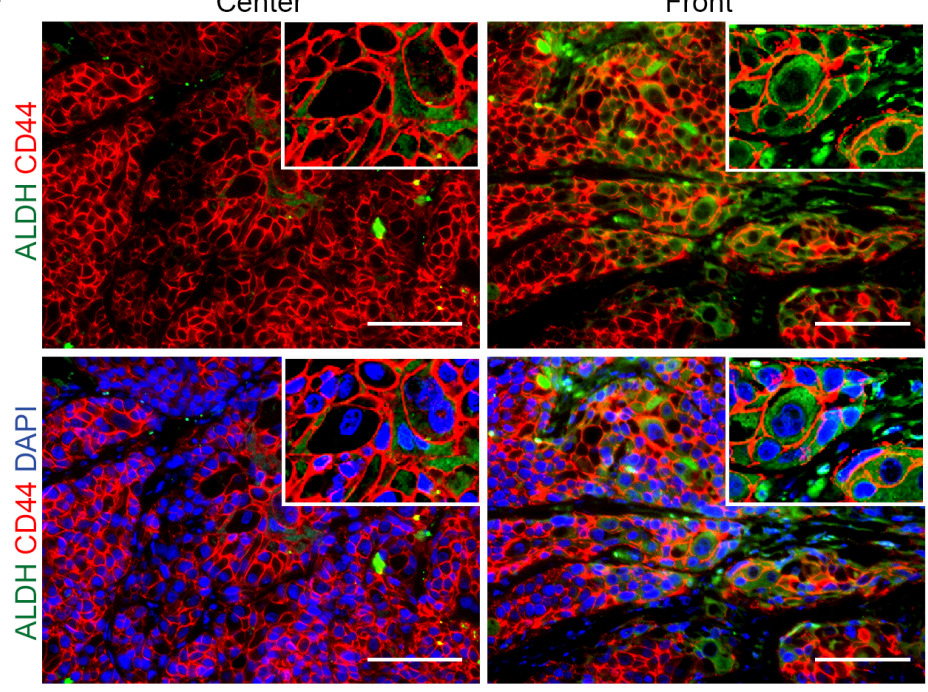

B

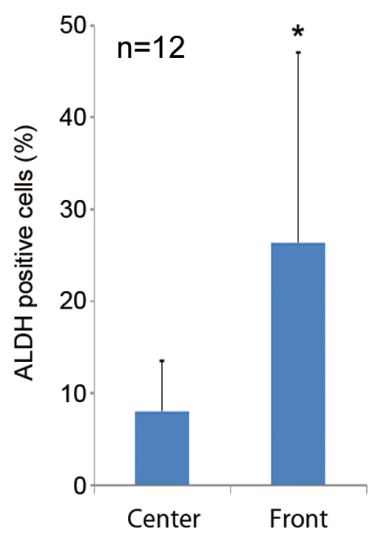

C

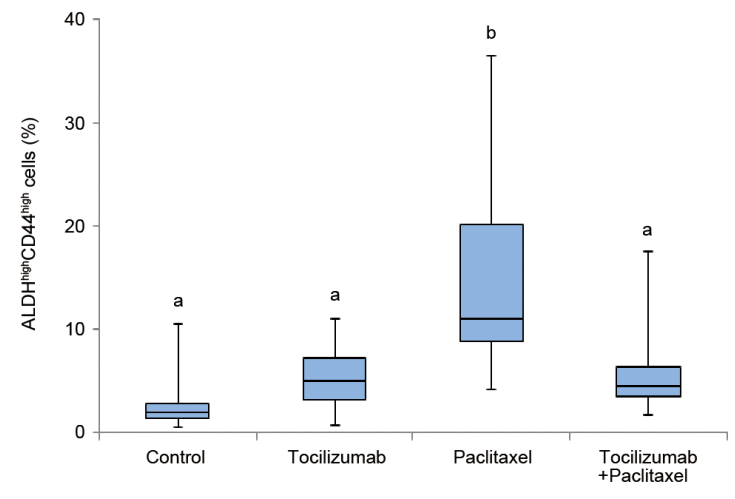

$\mathbf{E}$

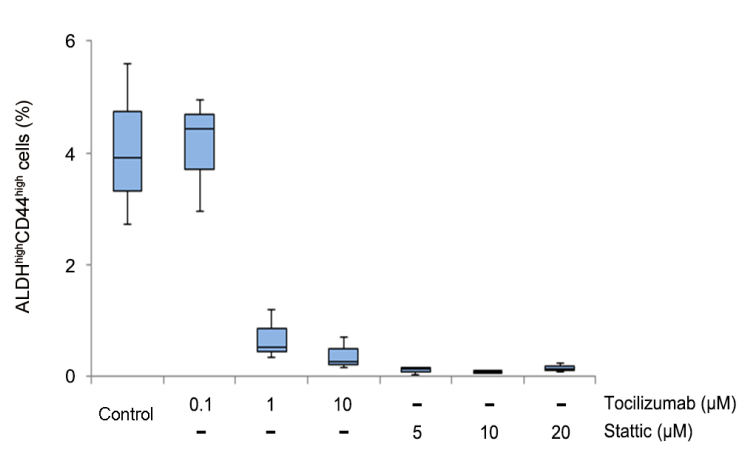

D

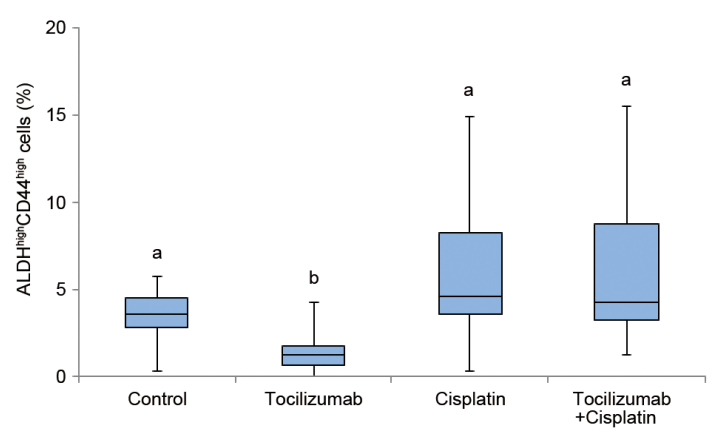

$\mathbf{F}$

G
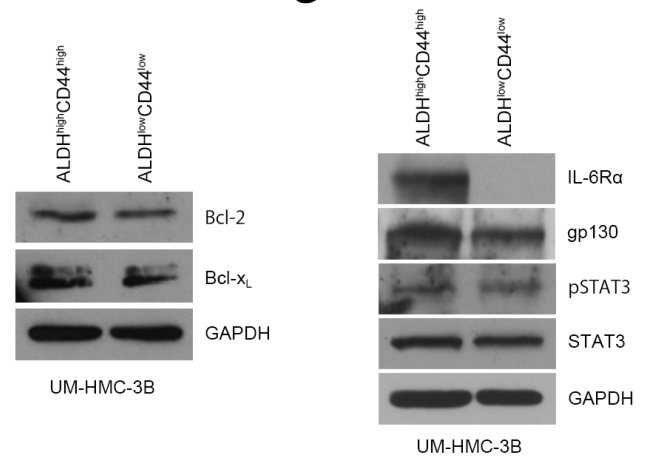

Figure 6: Effect of tocilizumab and paclitaxel on cancer stem cells in vivo. A. Representative images obtained by immunofluorescence for ALDH1 (green) and CD44 (red) in the center of human tumors and in the invasive front. Upper row pictures depict images without DAPI (blue), and lower pictures are with DAPI (x200). Scale bars represent $100 \mu \mathrm{m}$. B. Graph depicting the percentage of ALDH positive cells in the center and in the invasive front of the tumors. ALDH-positive cells were counted in 3 random fields from 4 tumors per condition. Asterisk $(*)$ depicts a statistical difference in the percentage of ALDH-positive cells when center and invasive fronts are compared $(P<0.05)$. C. and D. Graphs depicting the fraction of cancer stem cells (ALDH ${ }^{\text {high }}$ CD44 ${ }^{\text {high }}$ ) identified by flow cytometry in tumors treated with tocilizumab and/or paclitaxel C. or tocilizumab and/or cisplatin D. Different low-case letters indicate significant differences among groups $(P<0.05)$. E. Graph depicting the fraction of cancer stem cells ( $\mathrm{ALDH} \mathrm{H}^{\text {high }} \mathrm{CD} 44^{\text {high }}$ ) identified by flow cytometry in UM-HMC-3B cells treated with tocilizumab or Static for 24 hours. F. and $\mathbf{G}$. Western blots for Bcl-2 and Bcl- $\mathrm{X}_{\mathrm{L}} \mathbf{F}$. or phosphorylated and total STAT3, IL-6R, and gp130 G. in cancer stem cells (ALDH ${ }^{\text {high }}$ CD44 high) or control cells (ALDH ${ }^{\text {low }}{ }^{\text {he }} 44^{\text {low }}$ ) sorted from UM-HMC-3B cell line. 
vivo, we digested the xenograft tumors, generated singlecell suspensions, stained them for ALDH activity and CD44 expression, and sorted $\mathrm{ALDH}{ }^{\text {high }} \mathrm{CD} 44^{\text {high }}$ cells by flow cytometry. Therapy with tocilizumab by itself showed mixed results. In one experiment it did not have a significant effect on the fraction of $\mathrm{ALDH}{ }^{\text {high }} \mathrm{CD} 44^{\text {high }}$ cells (Figure 6C), while in the other experiment it decreased the fraction of cancer stem cells (Figure 6D). Paclitaxel treatment mediated a significant increase $(P<0.01)$ in the fraction of $\mathrm{ALDH}^{\text {high }} \mathrm{CD} 44^{\text {high }}$ cells (Figure 6C). However, adding tocilizumab to the treatment with paclitaxel mediated a return of the fraction of $\mathrm{ALDH}{ }^{\text {high }} \mathrm{CD} 44^{\text {high }}$ cells to baseline levels (Figure 6C). Cisplatin treatment did not cause a significant increase in the fraction of $\mathrm{ALDH}^{\text {high }} \mathrm{CD} 44^{\text {high }}$ cells, and its combination with tocilizumab had no measurable consequences (Figure 6D). We conclude from this set of experiments that the majority of the tumorigenic cancer stem cells are in the invasive fronts of xenograft mucoepidermoid carcinomas, and that tocilizumab inhibits paclitaxel-induced enrichment of the fraction of these cancer stem cells.

To further understand the effect of tocilizumab in the cancer stem cell fraction, we performed in vitro experiments with UM-HMC-3B cells treated with tocilizumab or with Stattic, a small molecule inhibitor of STAT3. Tocilizumab treatment resulted in a dosedependent reduction in the fraction of cancer stem cells (Figure 6E). Interestingly, direct inhibition of STAT3 with Stattic also decreased the fraction of cancer stem cells (Figure 6E). These effects were not simply due to differential expression of pro-survival proteins of the Bcl2 family in cancer stem cells, as compared to control cells (Figure 6F). Rather, the tocilizumab-mediated decrease in the fraction of cancer stem cells might be attributable to the differential expression of the receptor IL-6R, which is strongly expressed in $\mathrm{ALDH}^{\text {high }} \mathrm{CD} 44^{\text {high }}$ cells when compared to ALDH ${ }^{\text {low }} \mathrm{CD} 44^{\text {low }}$ cells (Figure 6G). Interestingly, the expression of gp130, total and phosphoSTAT3 was similar in both cancer stem cells and non-stem cells. Collectively, these results demonstrate that the effect of tocilizumab in the cancer stem cell fraction correlates with the increased expression of its target receptor (IL-6R) in mucoepidermoid carcinoma stem cells.

\section{DISCUSSION}

IL-6 plays a major role in the pathobiology of cancer. It is a key regulator of tumor cell proliferation, invasion and survival; it regulates the crosstalk between tumor cells and inflammatory cells, as well as vascular endothelial cells; and it enhances the survival and plasticity of cancer stem cells [17-25]. Such findings provided the rationale for clinical trials using targeted inhibitors of IL-6 in patients with cancer (e.g. ovarian cancer, multiple myeloma, renal cell carcinoma, prostate cancer) that showed promising results $[24,36-40]$. We have recently demonstrated that endothelial cell-secreted IL-6 regulates tumor growth [34] and the tumorigenic potential of cancer stem cells in head and neck squamous cell carcinomas [29]. We have also observed that mucoepidermoid carcinomas contain a population of uniquely tumorigenic cancer stem cells. However, we do not know the effect of inhibition of IL-6 signaling in mucoepidermoid carcinomas. Here, we showed that therapeutic inhibition of IL-6R with tocilizumab has no measurable effect on mucoepidermoid carcinoma cell viability, cell cycle, or sphere formation in vitro. Surprisingly, the in vivo studies showed very different results. Tocilizumab has a significant anti-tumor effect in xenograft mucoepidermoid carcinomas that correlated with potent inhibition of STAT3 signaling and inhibition of tumor angiogenesis. Single agent tocilizumab effect was similar to single agent paclitaxel or cisplatin, but tocilizumab was very much better tolerated by the mice. Tocilizumab further potentiated the anti-tumor effect of paclitaxel, and prevented paclitaxel-induced enrichment of cancer stem cells, without added toxicities. These results were correlated with a decrease in the cancer stem cell $\left(\mathrm{ALDH}{ }^{\text {high }} \mathrm{CD} 44^{\text {high }}\right)$ fraction mediated by Tocilizumab in vitro, and with the observation the cancer stem cells express higher levels of IL-6R when compared to control cells. Collectively, these data unveiled IL-6 as a therapeutic target for salivary gland mucoepidermoid carcinomas.

Patients with mucoepidermoid carcinoma are treated with surgery, radiation, and chemotherapy with taxanes or platinum-based drugs [5, 12-14, 41]. Treatment with these drugs is typically accompanied by severe systemic toxicities. Here, we observed that tocilizumab alone had similar anti-tumor effects when compared with paclitaxel or cisplatin. Notably, tocilizumab has been FDA-approved since 2010 for rheumatoid arthritis with an excellent record of safety for patients. The results of this preclinical study support the concept that tocilizumab could serve as a low-toxicity alternative to conventional chemotherapy in selected patients with mucoepidermoid carcinoma. We went a step forward, and performed drug combination studies that revealed that tocilizumab enhanced the antitumor effect of conventional chemotherapy, particularly paclitaxel. Indeed, we observed a significant improvement in time to failure when tocilizumab was used together with paclitaxel, when compared to monotherapy or vehicle controls. Notably, paclitaxel by itself enriched the fraction of the highly tumorigenic cancer stem cells, as it has been also demonstrated for other chemotherapeutic agents in head and neck cancer [30]. In contrast, addition of tocilizumab to the treatment with paclitaxel brought the fraction of cancer stem cells down to baseline levels. These results further suggest that the proposed combined therapy might be beneficial to patients. Nevertheless, additional studies are necessary to understand the longterm benefits of cancer stem cell ablation in preclinical models of mucoepidermoid carcinoma. 
We observed in several studies that tocilizumab is effective in vivo while has essentially no effect whatsoever in vitro. We speculate that this is due to its effect on angiogenesis and inflammation [42, 43], as well as its putative effect disrupting interactions between endothelial cells and cancer stem cells within the perivascular niches. There are several possible explanations for these intriguing results: A) We showed that endothelial cellderived IL-6 is critical for tumor growth [30]. Considering the well-known anti-angiogenic effect of IL-6 inhibition [20], and our own results demonstrating that tocilizumab inhibited tumor angiogenesis, it is possible that the antitumor effect of tocilizumab is mediated, at least in part, by decreased supply of oxygen and nutrients to tumor cells. B) By disrupting perivascular niches, i.e. the site where cancer stem cells typically reside in carcinomas [28], tocilizumab may disrupt this crosstalk between endothelial cells and cancer stem cells. We have recently showed that endothelial cell-secreted IL-6 enhances the tumorigenic potential of cancer stem cells [29]. Therefore, part of the effect observed here with tocilizumab might be mediated by interfering in this important crosstalk within the perivascular niche in vivo. And C) Tocilizumab is a potent inhibitor of STAT3 phosphorylation in vivo (Figure $1 \mathrm{~F})$. Considering the critical role of STAT3 signaling in cancer (e.g. regulation of VEGF expression and tumor angiogenesis, regulation of pro-inflammatory cytokines), it is possible that the effect of tocilizumab in vivo is mediated indirectly via blockade of downstream events induced by STAT3 signaling [44-47]. Such processes are not observable in vitro, and suggest that a true appreciation of the mechanisms underlying the therapeutic potential of tocilizumab require in vivo studies, at least in models of mucoepidermoid carcinoma.

IL-6 is clearly not the only endothelial cellderived factor that could potentially affect the behavior of mucoepidermoid carcinoma cells. Indeed, we have shown that endothelial cell-derived CXCL8 and EGF have significant effects on the survival and motility of head and neck squamous cell carcinoma cells [32, 33]. Here, we used endothelial cell conditioned medium as a physiological strategy to induce activation of major signaling pathways (i.e. STAT3, Akt, ERK) in mucoepidermoid carcinoma cells, to enable the study of potential effects of tocilizumab in these pathways. Surprisingly, despite the numerous cytokines/chemokines present in the endothelial cell conditioned medium, blockade of IL-6R signalling with Tocilizumab was sufficient to inhibit STAT3 phosphorylation below baseline levels (Figure 4F and 4G). Considering the prominent role of STAT3 signalling in the biology of cancer cells, these results provide further support to the therapeutic potential of IL-6R inhibition with tocilizumab in mucoepidermoid carcinoma.

In summary, patients with mucoepidermoid carcinoma have very few therapeutic options today, and most of them include radical surgical resection because these tumors simply do not respond to conventional chemotherapy [5, 12-16]. Here, we used recently characterized models of mucoepidermoid carcinoma and observed that single agent tocilizumab has similar antitumor effects as conventional chemotherapy, without significant systemic toxicities. Further, we observed that combination of tocilizumab with paclitaxel enhanced the anti-tumor effect without added toxicities, and prevented paclitaxel-induced accumulation of cancer stem cells. These results demonstrate the anti-tumor effect of tocilizumab, and suggest that patients with mucoepidermoid carcinoma might benefit from the targeted inhibition of IL-6R signaling.

\section{MATERIALS AND METHODS}

\section{Cells and reagents}

We used the University of Michigan-Human Mucoepidermoid Carcinoma cells (UM-HMC-1,-3A,-3B), a panel of cell lines recently generated and characterized by our laboratory [48]. Cells were cultured in Dulbecco's Modified Eagle's Medium (DMEM; Invitrogen, Carlsbad, CA, USA) supplemented with 10\% Fetal Bovine Serum (FBS; Invitrogen), 1\% 200 mM L-glutamine (Invitrogen), $20 \mathrm{ng} / \mathrm{ml}$ epidermal growth factor (EGF; Sigma-Aldrich, St. Louis, MO, USA), 400 ng/mL hydrocortisone (SigmaAldrich), $5 \mu \mathrm{g} / \mathrm{ml}$ insulin (Sigma-Aldrich), and $1 \%$ penicillin/streptomycin (Invitrogen) at $37^{\circ} \mathrm{C}$ with $5 \% \mathrm{CO}_{2}$. Primary human dermal microvascular endothelial cells (HDMEC; Lonza, Walkersville, MD, USA) were cultured in endothelial cell growth medium-2 for microvascular cells (EGM2-MV; Lonza). The experimental drugs used here were a humanized anti-IL-6R antibody (Tocilizumab; Genentech, San Francisco, CA, USA), control IgG (Jackson Laboratories, West Grove, PA, USA), cisplatin (Acros organics, Fairlawn, NJ, USA), and paclitaxel (Sagent pharmaceuticals, Schaumburg, IL, USA).

\section{Sulforhodamine B (SRB) assay}

SRB assays were performed to evaluate the effect of compounds on mucoepidermoid carcinoma cell viability, as described [49]. MEC cells (UM-HMC-1,-3A,-3B) were seeded at a density of $2 \times 10^{3}$ cells per well in $96-$-well plates, allowed to adhere overnight, and treated with drugs (or controls) for 72 hours. Plates were read in a microplate reader at $560 \mathrm{~nm}$ (GENios; Tecan, Granz, Austria). Data were obtained from triplicate wells per condition and are representative of at least 3 independent experiments. 


\section{Western blot analysis}

UM-HMC cell lines were plated, serum starved overnight, treated with tocilizumab or Stattic (STAT3 inhibitor V, Calbiochem, San Diego, CA, USA) at the indicated concentrations, and exposed to $20 \mathrm{ng} / \mathrm{ml} \mathrm{rhIL}$ 6 (R\&D Systems, Minneapolis, MN, USA). NP-40 lysis buffer was used to prepare whole cell lysates that were resolved using PAGE. Membranes were incubated with the following primary antibodies for 1 hour at room temperature or overnight at $4^{\circ} \mathrm{C}$ : mouse anti-human phospho-STAT3, rabbit anti-human STAT3, rabbit antihuman phospho-ERK1/2, rabbit anti-human ERK1/2, rabbit anti-human phospho-AKT, rabbit anti-human AKT, rabbit anti-human Bcl-x $\mathrm{x}_{\mathrm{L}}$, rabbit anti-human gp130 (Cell Signaling, Beverly, MA, USA), rabbit anti-human IL6R $\alpha$, rabbit anti-human VEGF (Santa Cruz Biotechnology, Santa Cruz, CA, USA), hamster anti-human Bcl-2 (BD Pharmingen, Franklin Lakes, NJ, USA); or mouse antiGAPDH (Chemicon, Billerica, MA, USA).

\section{Flow cytometry}

Cancer stem cells were identified as $\mathrm{ALDH}^{\text {high }} \mathrm{CD} 44^{\text {high }}$ cells, as we described [28-30]. Singlecell suspensions were obtained from the digestion of xenograft tumors or from the UM-HMC-3B cell line. Cells were counted, resuspended at $2 \times 10^{6}$ cells $/ \mathrm{ml}$ PBS, and incubated with activated Aldefluor ${ }^{\circledR}$ substrate (BAA) or the ALDH inhibitor (DEAB) for 45 minutes at $37^{\circ} \mathrm{C}$, using the Aldefluor ${ }^{\circledR}$ kit (StemCell; Vancouver, BC, Canada). Cells were exposed to anti-CD44 antibody (APC-Cat \#559942, PE-Cat \#550989) for 30 minutes at $4^{\circ} \mathrm{C}$. Anti-HLA-ABC (PE-Cat \#560168; BD Pharmingen) was used to separate human cells from mouse cells, and 7-AAD (Cat \#00-6993-50; eBiosciences, San Diego, CA, USA) staining was used to exclude dying cells. To measure the effect of drugs on cell cycle, UM-HMC-3B cells were treated with tocilizumab, cisplatin, paclitaxel, or controls diluted in cultured medium. After 24 hours, cells were retrieved, exposed to a hypotonic solution of propidium iodide containing $0.1 \%$ sodium citrate, 25 $\mu \mathrm{g} / \mathrm{ml}$ propidium iodide, $100 \mu \mathrm{g} / \mathrm{ml}$ RNase $\mathrm{A}$, and $0.1 \%$ Triton X-100. Cell cycle analysis was performed by flow cytometry, as described [50].

\section{Salisphere assay}

Non-adherent spheroids of mucoepidermoid carcinoma cells (named salispheres) were generated in ultra-low attachment 96-well plates (Corning; Corning, NY, USA) for 5 days with DMEM-F12 (Invitrogen) supplemented with 1\% N2 supplement (Invitrogen), 1\% GlutaMAX (Invitrogen), $1 \mu \mathrm{M}$ dexamethasone (Sigma-
Aldrich), $20 \mathrm{ng} / \mathrm{ml}$ EGF (Sigma-Aldrich), $20 \mathrm{ng} / \mathrm{mL}$ basic fibroblast growth factor (bFGF, Sigma-Aldrich), $10 \mu \mathrm{g} / \mathrm{ml}$ insulin (Sigma-Aldrich), and 1\% penicillin/streptomycin (Invitrogen).

\section{SCID mouse model of human tumor angiogenesis}

Porous poly-L-lactic acid scaffolds $(6 \times 6 \times 1 \mathrm{~mm})$ with an average pore diameter of $180 \mu \mathrm{m}$ were fabricated, as we described [51]. Just before transplantation, scaffolds were seeded with $7 \times 10^{5} \mathrm{HDMEC}$ and $3 \times 10^{5} \mathrm{UM}-\mathrm{HMC}$ 3B cells in a 1:1 Matrigel/EGM2-MV mix. Female severe combined immunodeficient mice (CB.17.SCID; Charles River Laboratory, Wilmington, MA, USA) were anesthetized with ketamine/xylazine, and two bilateral scaffolds were transplanted in the subcutaneous space of the dorsal region of each mouse. When the average tumor volume reached $200 \mathrm{~mm}^{3}$, mice were randomized into the following treatment conditions: $5 \mathrm{mg} / \mathrm{kg} \mathrm{IgG}$ control, $5 \mathrm{mg} / \mathrm{kg}$ tocilizumab, $5 \mathrm{mg} / \mathrm{kg}$ cisplatin and/or 15 $\mathrm{mg} / \mathrm{kg}$ paclitaxel administered weekly via intraperitoneal injection. When 2 drugs were combined (e.g. tocilizumab + paclitaxel), they were administered with a 12-hour interval between them. Tumors were surgically retrieved when they reached $1,000 \mathrm{~mm}^{3}$, fixed overnight in $10 \%$ buffered formalin (Fisher Scientific, Pittsburgh, PA, USA) at $4^{\circ} \mathrm{C}$, and processed for immunohistochemistry. Tumor size was calculated using the formula: volume $\left(\mathrm{mm}^{3}\right)=L$ $\times W^{2} / 2$ ( $L$, length; $W$, width). The care and treatment of experimental animals was in accordance with University of Michigan institutional guidelines.

\section{Immunofluorescence and Immunohistochemistry}

Tissue sections were incubated at $60^{\circ} \mathrm{C}$ for 20 minutes, deparafinized in xylene twice for 10 minutes, washed with $100 \%$ ethanol twice for 5 minutes, and then rehydrated with graded ethanol. Antigen retrieval was performed with Target Retrieval Solution (Dako, Carpinteria, CA, USA) following manufacturer's instructions, and the slides were washed with PBS thrice at room temperature. Endogenous peroxidase activity was quenched by 10-minute incubation in 3\% hydrogen peroxide in PBS. Primary antibodies against ALDH1 (Abcam, Cambridge, England), IL-6 (Abcam), IL-6R (Santa Cruz Biotechnology), gp130 (Santa Cruz Biotechnology), CD44 (Thermo Scientific, Rockford, IL, USA), and pSTAT3 (Cell Signaling) were prelabeled with Alexafluor 488 or 594 using a Zenon labeling kit, and Prolong Gold Anti-fade Reagent with DAPI (Invitrogen) was used to mount the slides. Immunofluorescence images were taken with a Nikon Eclipse 80i fluorescence microscope, and image processing was done with Q-Capture Pro 7 (Q-imaging) and NIH ImageJ. Alternatively, tissue sections were incubated in Target 
Retrieval Solution (Dako) for $20 \mathrm{~min}$ at $90-95^{\circ} \mathrm{C}$, followed by incubation with primary antibody at $4^{\circ} \mathrm{C}$ overnight. Polyclonal anti-human factor VIII antibody (Thermo Scientific) was used to identify microvascular networks, as described [52]. Blood vessels were counted in 5 random fields/tumor from 5 tumors per experimental condition.

\section{Statistical analyses}

Statistical analysis was performed using Welch's $t$-test, Kruskal-Wallis tests, or one-way ANOVA followed by appropriate post-hoc tests. Kaplan-Meier curves were analyzed with the Gehan's generalized Wilcoxon tests. Tumor regression was analyzed using a linear mixed model regression to analyze the repeated measurements on each tumor. Model fixed effects included time, tocilizumab, chemotherapy, and the interaction of treatments and time. Model random effects included both mouse and tumor position. For all models a continuous autoregressive correlation structure was used, which assumes more correlated variances among temporally proximate observations. A log-transformation of the outcome variable (tumor volume) was used because the tumor volumes follow an exponential increase. Size at study initiation was also controlled for. Analysis was performed using the "nlme" package in the statistical software program R version 3.1.0. (2008; R Development Core Team). R: A language and environment for statistical computing. R Foundation for Statistical Computing, Vienna, Austria. (http://www.R-project.org.) Statistical significance was determined at $P<0.05$.

\section{ACKNOWLEDGMENTS}

We thank the patients who kindly provided the tumor specimens used here to generate the mucoepidermoid carcinoma cell lines and xenograft models needed for this research. We thank the University of Michigan Flow Cytometry Core and the Histology Core for their expert support to this project.

\section{FINANCIAL SUPPORT}

This work was funded by the University of Michigan Head Neck SPORE P50-CA-97248, from the NIH/NCI; and by grants R21-DE19279, R01-DE23220 and R01-DE21139 from the NIH/NIDCR (JEN)

\section{CONFLICTS OF INTEREST}

The authors have no conflict of interest to declare.

\section{REFERENCES}

1. Gillespie MB, Albergotti WG, Eisele DW. Recurrent salivary gland cancer. Curr Treat Options Oncol. 2012; 13: 58-70.

2. Andry G, Hamoir M, Locati LD, Licitra L, Langendijk JA. Management of salivary gland tumors. Expert Rev Anticancer Ther. 2012; 12: 1161-1168.

3. To VSH, Chan JYW, Tsang RKY, Wei WI. Review of Salivary Gland Neoplasms. ISRN Otolaryngol. 2012; 2012: $1-6$.

4. Barnes EL, Eveson JW, Reichart P SD. World Health Organization classification of tumours: pathology and genetics of head and neck in tumours. IARCpress, Lyon. 2005: 209-281.

5. Adelstein DJ, Koyfman SA, El-Naggar AK, Hanna EY. Biology and management of salivary gland cancers. Semin Radiat Oncol. 2012; 22: 245-253.

6. Luna MA. Salivary mucoepidermoid carcinoma: revisited. Adv Anat Pathol. 2006; 13: 293-307.

7. Chen AM, Lau VH, Farwell DG, Luu Q, Donald PJ. Mucoepidermoid carcinoma of the parotid gland treated by surgery and postoperative radiation therapy: clinicopathologic correlates of outcome. Laryngoscope. 2013; 123: 3049-3055.

8. Liu S, Ow A, Ruan M, Yang W, Zhang C, Wang L. Prognostic factors in primary salivary gland mucoepidermoid carcinoma: an analysis of 376 cases in an Eastern Chinese population. Int J Oral Maxillofac Surg 2014; 43:667-673.

9. McHugh $\mathrm{CH}$, Roberts DB, El-Naggar AK, Hanna EY, Garden AS, Kies MS, Weber RS, Kupferman ME. Prognostic factors in mucoepidermoid carcinoma of the salivary glands. Cancer. 2012; 118: 3928-3936.

10. Lima RA, Tavares MR, Dias FL, Kligerman J, Nascimento MF, Barbosa MM, Cernea CR, Soares JR, Santos IC, Salviano S. Clinical prognostic factors in malignant parotid gland tumors. Otolaryngol Head Neck Surg. 2005; 133: 702-708.

11. Spiro RH, Thaler HT, Hicks WF, Kher UA, Huvos AH, Strong EW. The importance of clinical staging of minor salivary gland carcinoma. Am J Surg. 1991; 162: 330-336.

12. Laurie SA, Licitra L. Systemic therapy in the palliative management of advanced salivary gland cancers. J Clin Oncol. 2006; 24: 2673-2678.

13. Lagha A, Chraiet N, Ayadi M, Krimi S, Allani B, Rifi H, Raies H, Mezlini A. Systemic therapy in the management of metastatic or advanced salivary gland cancers. Oral Oncol. 2012; 48: 948-957.

14. Laurie SA, Ho AL, Fury MG, Sherman E, Pfister DG. Systemic therapy in the management of metastatic or locally recurrent adenoid cystic carcinoma of the salivary glands: a systematic review. Lancet Oncol. 2011; 12: 815824.

15. Schoenfeld JD, Sher DJ, Norris CM, Haddad RI, Posner MR, Balboni TA, Tishler RB. Salivary gland tumors treated with adjuvant intensity-modulated radiotherapy with or 
without concurrent chemotherapy. Int J Radiat Oncol Biol Phys. 2012; 82: 308-314.

16. Gilbert J, Li Y, Pinto HA, Jennings T, Kies MS, Silverman $\mathrm{P}$, Forastiere AA. Phase II trial of taxol in salivary gland malignancies (E1394): a trial of the Eastern Cooperative Oncology Group. Head Neck. 2006; 28: 197-204.

17. Sansone P, Storci G, Tavolari S, Guarnieri T, Giovannini C, Taffurelli M, Ceccarelli C, Santini D, Paterini P, Marcu $\mathrm{KB}$, Chieco P, Bonafè M. IL-6 triggers malignant features in mammospheres from human ductal breast carcinoma and normal mammary gland. J Clin Invest. 2007; 117: 39884002 .

18. Wang H, Lathia JD, Wu Q, Wang J, Li Z, Heddleston JM, Eyler CE, Elderbroom J, Gallagher J, Schuschu J, MacSwords J, Cao Y, McLendon RE, et al. Targeting interleukin 6 signaling suppresses glioma stem cell survival and tumor growth. Stem Cells. 2009; 27: 2393-2404.

19. Kim S-Y, Kang JW, Song X, Kim BK, Yoo YD, Kwon YT, Lee YJ. Role of the IL-6-JAK1-STAT3-Oct-4 pathway in the conversion of non-stem cancer cells into cancer stemlike cells. Cell Signal. 2013; 25: 961-969.

20. Shinriki S, Jono H, Ota K, Ueda M, Kudo M, Ota T, Oike Y, Endo M, Ibusuki M, Hiraki A, Nakayama H, Yoshitake Y, Shinohara M, et al. Humanized anti-interleukin-6 receptor antibody suppresses tumor angiogenesis and in vivo growth of human oral squamous cell carcinoma. Clin Cancer Res. 2009; 15: 5426-5434.

21. Guo Y, Nemeth J, O'Brien C, Susa M, Liu X, Zhang Z, Choy E, Mankin H, Hornicek F, Duan Z. Effects of siltuximab on the IL-6-induced signaling pathway in ovarian cancer. Clin Cancer Res. 2010; 16: 5759-5769.

22. Song L, Smith MA, Doshi P, Sasser K, Fulp W, Altiok S, Haura EB. Antitumor efficacy of the anti-interleukin-6 (IL6) antibody siltuximab in mouse xenograft models of lung cancer. J Thorac Oncol. 2014; 9: 974-982.

23. Ara T, Nakata R, Sheard MA, Shimada H, Buettner R, Groshen SG, Ji L, Yu H, Jove R, Seeger RC, DeClerck YA. Critical role of STAT3 in IL-6-mediated drug resistance in human neuroblastoma. Cancer Res. 2013; 73: 3852-3864.

24. Dorff TB, Goldman B, Pinski JK, Mack PC, Lara PN, Van Veldhuizen PJ, Quinn DI, Vogelzang NJ, Thompson IM, Hussain MHA. Clinical and correlative results of SWOG S0354: A phase II trial of CNTO328 (siltuximab), a monoclonal antibody against interleukin-6, in chemotherapy-pretreated patients with castration-resistant prostate cancer. Clin Cancer Res. 2010; 16: 3028-3034.

25. Kroon P, Berry PA, Stower MJ, Rodrigues G, Mann VM, Simms M, Bhasin D, Chettiar S, Li C, Li PK, Maitland NJ, Collins AT. JAK-STAT blockade inhibits tumor initiation and clonogenic recovery of prostate cancer stem-like cells. Cancer Res. 2013; 73: 5288-5298.

26. Duffy SA, Taylor JMG, Terrell JE, Islam M, Li Y, Fowler KE, Wolf GT, Teknos TN. Interleukin-6 predicts recurrence and survival among head and neck cancer patients. Cancer.
2008; 113: 750-757.

27. Duffy SA, Teknos T, Taylor JMG, Fowler KE, Islam M, Wolf GT, McLean S, Ghanem TA, Terrell JE. Health behaviors predict higher interleukin-6 levels among patients newly diagnosed with head and neck squamous cell carcinoma. Cancer Epidemiol Biomarkers Prev. 2013; 22: 374-381.

28. Krishnamurthy S, Dong Z, Vodopyanov D, Imai A, Helman JI, Prince ME, Wicha MS, Nör JE. Endothelial cell-initiated signaling promotes the survival and self-renewal of cancer stem cells. Cancer Res. 2010; 70: 9969-9978.

29. Krishnamurthy S, Warner KA, Dong Z, Imai A, Nör C, Ward BB, Helman JI, Taichman RS, Bellile EL, McCauley LK, Polverini PJ, Prince ME, Wicha MS, et al. Endothelial interleukin- 6 defines the tumorigenic potential of primary human cancer stem cells. Stem Cells. 2014; 32: 2845-2857.

30. Nör C, Zhang Z, Warner KA, Bernardi L, Visioli F, Helman JI, Roesler R, Nör JE. Cisplatin induces bmi-1 and enhances the stem cell fraction in head and neck cancer. Neoplasia. 2014; 16: 137-148.

31. Warner KA, Miyazawa M, Cordeiro MMR, Love WJ, Pinsky MS, Neiva KG, Spalding AC, Nör JE. Endothelial cells enhance tumor cell invasion through a crosstalk mediated by CXC chemokine signaling. Neoplasia. 2008; 10:131-139.

32. Neiva KG, Zhang Z, Miyazawa M, Warner KA, Karl E, Nör JE. Cross talk initiated by endothelial cells enhances migration and inhibits anoikis of squamous cell carcinoma cells through STAT3/Akt/ERK signaling. Neoplasia. 2009; 11:583-593.

33. Zhang Z, Dong Z, Lauxen IS, Filho MSA, Nör JE. Endothelial cell-secreted EGF induces epithelial to mesenchymal transition and endows head and neck cancer cells with stem-like phenotype. Cancer Res. 2014; 74:28692881.

34. Neiva KG, Warner KA, Campos MS, Zhang Z, Moren J, Danciu TE, Nör JE. Endothelial cell-derived interleukin-6 regulates tumor growth. BMC Cancer. 2014; 14: 99.

35. Krishnamurthy S, Nör JE. Orosphere assay: a method for propagation of head and neck cancer stem cells. Head Neck. 2013; 35: 1015-1021.

36. Coward J, Kulbe H, Chakravarty P, Leader D, Vassileva V, Leinster DA, Thompson R, Schioppa T, Nemeth J, Vermeulen J, Singh N, Avril N, Cummings J, et al. Interleukin-6 as a Therapeutic Target in Human Ovarian Cancer. Clin Cancer Res. 2011; 17: 6083-6096.

37. Moreau P, Harousseau JL, Wijdenes J, Morineau N, Milpied N, Bataille R. A combination of anti-interleukin 6 murine monoclonal antibody with dexamethasone and high-dose melphalan induces high complete response rates in advanced multiple myeloma. Br J Haematol. 2000; 109: 661-664.

38. Rossi J-F, Négrier S, James ND, Kocak I, Hawkins R, Davis H, Prabhakar U, Qin X, Mulders P, Berns B. A phase I/ 
II study of siltuximab (CNTO 328), an anti-interleukin-6 monoclonal antibody, in metastatic renal cell cancer. Br J Cancer. 2010; 103: 1154-1162.

39. Karkera J, Steiner H, Li W, Skradski V, Moser PL, Riethdorf S, Reddy M, Puchalski T, Safer K, Prabhakar U, Pantel K, Qi M, Culig Z. The anti-interleukin-6 antibody siltuximab down-regulates genes implicated in tumorigenesis in prostate cancer patients from a phase I study. Prostate. 2011; 71: 1455-1465.

40. Fizazi K, De Bono JS, Flechon A, Heidenreich A, Voog E, Davis NB, Qi M, Bandekar R, Vermeulen JT, Cornfeld M, Hudes GR. Randomised phase II study of siltuximab (CNTO 328), an anti-IL-6 monoclonal antibody, in combination with mitoxantrone/prednisone versus mitoxantrone/prednisone alone in metastatic castrationresistant prostate cancer. Eur J Cancer. 2012; 48: 85-93.

41. Laurie SA, Siu LL, Winquist E, Maksymiuk A, Harnett EL, Walsh W, Tu D, Parulekar WR. A phase 2 study of platinum and gemcitabine in patients with advanced salivary gland cancer: a trial of the NCIC Clinical Trials Group. Cancer. 2010; 116: 362-368.

42. Eldesoky A, Shouma A, Mosaad Y, Elhawary A. Clinical Relevance of Serum Vascular Endothelial Growth Factor and Interleukin-6 in Patients with Colorectal Cancer. Saudi J Gastroenterol. 2011; 17: 170-173.

43. Chen M-F, Chen P-T, Lu MS, Lin PY, Chen W-C, Lee K-D. IL-6 expression predicts treatment response and outcome in squamous cell carcinoma of the esophagus. Mol Cancer. 2013; 12: 26.

44. Ling X, Arlinghaus RB. Knockdown of STAT3 expression by RNA interference inhibits the induction of breast tumors in immunocompetent mice. Cancer Res. 2005; 65: 25322536.

45. Hedvat M, Huszar D, Herrmann A, Gozgit JM, Schroeder A, Sheehy A, Buettner R, Proia D, Kowolik CM, Xin $\mathrm{H}$, Armstrong B, Bebernitz G, Weng S, et al. The JAK2 inhibitor AZD1480 potently blocks Stat3 signaling and oncogenesis in solid tumors. Cancer Cell. 2009; 16: 487497.

46. Duan Z, Foster R, Bell DA, Mahoney J, Wolak K, Vaidya A, Hampel C, Lee H, Seiden M V. Signal transducers and activators of transcription 3 pathway activation in drugresistant ovarian cancer. Clin Cancer Res. 2006; 12: 50555063.

47. Middleton K, Jones J, Lwin Z, Coward JIG. Interleukin-6: An angiogenic target in solid tumours. Crit Rev Oncol Hematol. 2014; 89: 129-139.

48. Warner KA, Adams A, Bernardi L, Nor C, Finkel KA, Zhang Z, McLean SA, Helman J, Wolf GT, Divi V, Queimado L, Kaye FJ, Castilho RM, et al. Characterization of tumorigenic cell lines from the recurrence and lymph node metastasis of a human salivary mucoepidermoid carcinoma. Oral Oncol. 2013; 49: 1059-1066.

49. Skehan P, Storeng R, Scudiero D, Monks A, Vistica D,
Warren JT, Bokesch H, Boyd MR. New colorimetric cytotoxicity assay for anticancer-drug screening. J Natl Cancer Inst. 1990; 82: 1107-1112.

50. Ashimori N, Zeitlin BD, Zhang Z, Warner K, Turkienicz IM, Spalding AC, Teknos TN, Wang S, Nör JE. TW-37, a small-molecule inhibitor of Bcl-2, mediates S-phase cell cycle arrest and suppresses head and neck tumor angiogenesis. Mol Cancer Ther. 2009; 8: 893-903.

51. Nör JE, Peters MC, Christensen JB, Sutorik MM, Linn S, Khan MK, Addison CL, Mooney DJ, Polverini PJ. Engineering and characterization of functional human microvessels in immunodeficient mice. Lab Invest. 2001; 81: 453-463.

52. Nör JE, Christensen J, Mooney DJ, Polverini PJ. Vascular endothelial growth factor (VEGF)-mediated angiogenesis is associated with enhanced endothelial cell survival and induction of Bcl-2 expression. Am J Pathol. 1999; 154: 375384. 